\title{
Expression of HERV-H/W env epitopes on PBMCs from MS patients with active disease
}

\author{
Tomasz Brudek ${ }^{1,2}$, Tove Christensen ${ }^{1}$, Thor Petersen ${ }^{3}$, Anné Møller-Larsen ${ }^{1 *}$ \\ From 15th International Conference on Human Retroviruses: HTLV and Related Viruses \\ Leuven and Gembloux, Belgium. 5-8 June 2011
}

\section{Background}

The demyelinating disease Multiple Sclerosis (MS) is assumed to be caused by a malfunction of the immune system, maybe due to exposure of genetically susceptible individuals to unknown environmental agent(s) - possibly virus. Our working hypothesis is that these viruses could be endogenous retroviruses, activated by other infectious agents, presumably from the herpes virus group with EBV as the prime candidate. Previously retroviral activity has been monitored by PERT assays. Assays such as flow cytometry enables detection of possible expression of viral epitopes on the surface of PBMCs from MSpatients, and confocal microscopy can show the cellular location of these epitopes.

\section{Materials and methods}

Polyclonal rabbit antibodies against HERV-H/W Env SUand TM-regions were used in flow cytometry to detect cell-membrane expression of these epitopes on PBMCs from MS patients in different disease states compared with healthy individuals, and patients with other neurological diseases. Monoclonal antibodies against CD-epitopes were used to quantitate the different PBMCs expressing the HERV-epitopes. The rabbit antibodies were also used in labeling of long-term, spontaneously growing, lymphoblastoid cell-cultures from MS patients to localize viral epitopes on the cell surfaces.

\section{Results}

The flow cytometric analyses detect increased quantities of HERV-H/W Env epitopes on B-cells and monocytes together with increased numbers of B-cells in patients with active MS. Confocal microscopy show expression

\footnotetext{
* Correspondence: aml@microbiology.au.dk

'Department of Medical Microbiology and Immunology, Aarhus University, Aarhus C, DK-8000, Denmark

Full list of author information is available at the end of the article
}

of viral epitopes on the surface of the lymphoid cell cultures.

\section{Conclusions}

The findings demonstrate higher expression of HERV-H/ W Env epitopes on the surface of some types of PBMCs from patients with active MS.

\section{Author details}

'Department of Medical Microbiology and Immunology, Aarhus University, Aarhus C, DK-8000, Denmark. ${ }^{2}$ Research Laboratory for Stereology and Neuroscience, Bispebjerg University Hospital, København NV, DK-2400, Denmark. ${ }^{3}$ Department of Neurology, Aarhus University Hospital, Aarhus C, DK-8000, Denmark.

Published: 6 June 2011

doi:10.1186/1742-4690-8-S1-A210

Cite this article as: Brudek et al:: Expression of HERV-H/W env epitopes on PBMCs from MS patients with active disease. Retrovirology 20118 (Suppl 1):A210.
Submit your next manuscript to BioMed Central and take full advantage of:

- Convenient online submission

- Thorough peer review

- No space constraints or color figure charges

- Immediate publication on acceptance

- Inclusion in PubMed, CAS, Scopus and Google Scholar

- Research which is freely available for redistribution
() Bïomed Central

\section{Biomed Central}

